\title{
“Los Mirreyes de Outlet”: A Critical Discourse Analysis on a Broadcast Portraying the Postmodern Lifestyle of Mexican Middle Class
}

\author{
Rosalina Romo Molinares \\ University of Guanajuato, Division of Social Sciences and Humanities
}

Received 1 October 2018 • Revised 25 November 2018 • Accepted 29 November 2018

\begin{abstract}
Through the rise of social media and mass communication social phenomena acquires major popularity levels. In Mexico, "el mirreynato" is a trendy phenomenon that has increased its status through social media. The popularity is such that a Latin-American network broadcasted a report on this matter. The report's transparent intention was to present "mirreyes de outlet" and describe their activities. This critical discourse analysis aimed at uncovering the opaque intention, behind this report. Through the use of systemic functional linguistics, it was found that the discourse used in this report had a different intention than the transparent purpose mentioned by the network.
\end{abstract}

Keywords: critical discourse analysis, transitivity, modality, textual, opaque meaning, social divisions, stereotypes.

\section{Introduction}

Mexico is currently facing a social phenomenon called "el mirreynato" which means the reign of mirreyes. According to Espinosa \& Henderson (2012) a "mirrey" is the term used to describe the high privileged social class. Mirreyes are believed to have the following characteristics: wealthy, prestigious family, good looks, dresses in brand name clothing, popular, travels, powerful, and is constantly surrounded by VIP society. The popularity of this group is such that individuals aspire being "mirreyes" yet, scarcely anyone becomes part of the selected group. Those who do not meet the demanding characteristics of a real "mirrey" are labeled as "mirreyes de outlet". This label depicts individuals who on the outside may appear and behave as a 'mirrey" nevertheless, their origins are in working middle class.

Recently the television network Univision (Latin network in the United States) presented a report on the marginalized group "mirreyes de outlet". They titled the report "¿Quiénes son y qué hacen los mirreyes de outlet? / Who are "mirreyes de outlet and what do they do?" and it was presented in the show "Aquí y Ahora/ Here and now". The transparent aim of the report was to describe the lifestyles of "mirreyes de outlet" by presenting their main characteristics and their daily routines. This paper presents a critical discourse analysis (CDA) with the aim of analyzing this report in order to uncover the opaque or hidden intention. The analysis is divided into three sections, transitivity, modality and textual. To conclude I present the social repercussions of the report and a call of action in search of social justice.

(c) Authors. Terms and conditions of Creative Commons Attribution 4.0 International (CC BY 4.0) apply. Correspondence: Rosalina Romo Molinares, Lascuráin de Retana No. 5, Colonia Centro, Código Postal 3600o, MEXICO. E-mail: rosalina_15@hotmail.com. 
R. R. Molinares - “Los Mirreyes de Outlet”: A Critical Discourse Analysis on a Broadcast...

- The central element to the social phenomenon of "El mirreynato" is the notion of power.

- Beyond the humorous labels and popularity of this social phenomenon this report portrays a social problem of dominance and inequities.

- Through the use of systemic functional linguistics, it was found that the discourse used in this report had a different intention than the transparent purpose mentioned by the network.

\section{Theoretical Framework}

Prior to presenting the critical discourse analysis, it crucial to understand the central phenomenon that is under study in this paper. To provide this understanding, I shall first provide the historical background, in which I explain why and how this became a social matter of interest. Subsequently, I discuss the relevant social concepts behind the phenomenon.

\subsection{Historical background on social phenomenon}

"El mirreynato" has recently increased its popularity through the rise of communication and social media. Nonetheless this is not a new phenomenon, class divisions and stereotypes have existed long in history. In Mexico, the first label for high class appeared in the 80 and the terms used were "juniors", "niños popis4" or "hijos de papi" (Feixa, 1998: 102). The term mirrey was first figured in the 90s, however its origins are uncertain. Espinosa and Henderson (2012) explain the word could be associated with the prominent singer of the decade Luis Miguel who was often referred to as "Luis Mirrey". The signer was not only recognized by his music but also by his luxurious lifestyle. This artist is said to be the best example of a mirrey and an inspiration to many. It is also believed that it could have originated from the typical paternal expression “¿cómo estas mi rey?” (Espinosa \& Henderson, 2012). Although its origin is uncertain, it is clear that ever since then word mirrey has normally been used to name high class in Mexico.

As previously stated, the high status quo of this group has led many to aspire being part of it. Those who do not meet the requirements but have some characteristics are labelled as "mirreyes de outlet" or "shabbys". Although they are not real mirreyes they try to imitate the luxurious lifestyle by: spending money on personal care, clothing, visiting exclusive night clubs and fancy restaurants. They appear on social media with the famous "duckface" in which their lips seem to be sending a kiss. They are also recognized by their particular use of language; they speak as "fresas 5 " by making longer sounds for vowels and speaking as if they had a potato in their mouth (Espinosa \& Henderson, 2012). Even though these individuals have the appearance and lifestyle of a mirrey, they do not have the same socioeconomic level and have to work intensively to enjoy these luxuries.

With the above in mind "mirreyes de outlet", have to face challenges and work hard to access this lifestyle. Aside from their daily struggles they must also cope with social marginalization. The real mirreyes ridicule them by defining them as a "una copia barata" cheap version (Espinosa \& Henderson, 2012). The lower class also mocks and marginalizes them; there are several YouTube channels and webpages used for this purpose. For instance, "Mirreybook de outlet un sincero homenaje para aquellos que no lo lograron/ Mirreybook de outlet a sincere tribute to those who did not make it" is Tumblr website that portrays mirreyes de outlet with a photograph and a legend that mocks the way they dress, their behaviors among other aspects.

\subsection{Theoretical concepts of social phenomenon}

The central element to the social phenomenon of "El mirreynato" is the notion of power. Foucault (1997) explains that power is not something some can be held, but it is exercised 
in none egalitarian situations which reinforce divisions and inequities. In this case, mirreyes use their social power to marginalize and create greater divisions the Mexican society. These social divisions or class divisions are all based on economic status of the individuals (Martin, 2003). Unfortunately, this is the way society works, power is used to divide people into groups according to economic status.

In Mexico, the sociologists Carlos Feixa and Jose Manuel Valenzuela have researched into the existing social divisions of young adults. Feixa (1998) identified that in our country there are subaltern social divisions that are grouped according to two aspects: social conditions and cultural images. The author refers to age gender, social class, and ethnic background as social conditions, while ideological attributes, trends, musical preferences, and languages practices as cultural images. On the other hand, Valenzuela (2009) explains the Mexican society is divided into three types of social groups; marginalized, tolerated, and encouraged social groups. The marginalized social sectors are those are rejected by most of society could be any of the following "pachucos", hippies, punks, etc. The tolerated group are those individuals who do not represent any moral or ideological problems to the dominant society. While the encouraged social groups are those who work towards stimulating the dominant ideologies, such as religious and political groups.

In addition to the concepts of power and class division I also use the terms postmodernity and lifestyle. Postmodernity has been characterized by the rise of mass communication, media, mass consumption (Martin, 2003). All which benefits global economies and high class but affects the low and middle working class. With the growth of mass consumption and mass media people have created a need to define the way they live and the term lifestyle has come to live (Jagose, 2003). Historically there had not been a need to define the type of life one had, yet now most of the population uses the term to describe their everyday life. Lifestyles are routines that discuss personal habits, for instance dressing and eating habits (Giddens, 1991). Moreover, postmodernity has brought social media, which is an online space where people post information that reveals their lifestyles.

\section{Critical discourse analysis as research methodology}

This analysis sets out to examine a broadcast portraying the postmodern lifestyle of Mexican middle class report to uncover the opaque or hidden intention. In order to conduct this examination CDA was employ as the research methodology. Fairclough (2001) argues that CDA is a method that can be utilized to research into scientific social areas due to the following reasons. It is first crucial to point out that CDA has its roots in critical science; van Dijk (1986) states that critical science goes beyond descriptions, superficial applications, and theoretical problems. The beauty lies in that it goes further into questioning responsibility, interest, and ideology, in order to explore social problems. Hence, the word critique stands for this type of questioning in which we seek to find the interconnectedness of things as cause and effects (Fairclough, 1985: 747). The main purpose behind this type of science is approaching those who are marginalized by analyzing those in power.

Consequently, critical discourse analysis goes beyond analyzing the linguistic elements in discourse. It focuses in the interconnectedness of language to the concepts of power and ideology to understand how language is used for dominance and discrimination (Wodak, 2001). Furthermore, in this type of analysis, language is viewed as a social practice and takes in consideration the social context of the discourse (Fairclough \& Wodak, 1997). Most importantly language is understood to be "a medium of dominance and social force" (Habermas, 1977 p. 259). Therefore, CDA is suited to uncover the opaque intention behind the broadcast report. 


\subsection{Research technique: Systemic functional linguistics}

Systemic functional linguistics was first introduced by Michael Alexander Kirkwood Halliday and ever since its introduction it has been used for critical discourse analysis. Halliday (1978) explains that discourse is a multidimensional process which is not only composed of lexicogrammatical choices but also by higher levels of functions like semiotics. In other words, the social, physical, cognitive, cultural, interpersonal and situational context play an important role in discourse choice (Haratyan, 2011).

Halliday (1978: 332) also highlights that this multidimensional process comprises three functions: ideational, interpersonal, and textual. The ideational function refers to the speakers combining transitivity (grammar) and his/her voice to express "reactions, cognitions, and perceptions". Within this function there are six processes that we use to communicate these are; material, mental, relational, verbal, behavioural, and existential processes. The material process indicates an action with a direct object while the mental is only used for perceptions and reactions. Verbal processes are used to exchange information or describe, similarly the relational process is used to identify or attribute characteristics. We also express physiological or mental behaviors through the behavioral process. Lastly, we use the existential process to present something that exist or happens.

The interpersonal function of language is the expressions of the individual's "comments, attitudes, and evaluations in relation to the particular communication roles" (Halliday, 1978: 333). The communicative roles are informing, questioning, or giving commands. The third function presented by Halliday is the textual function in which language is organized coherently to help the listener or reader understand the message.

\section{Results of the analysis}

The analysis is divided into three sections, first the transitivity analysis in which I classify the data into the six processes. The second part of the analysis concerns the interpersonal function providing a modality analysis. The last part of the analysis specifically looks at the textual function in order to understand how content of the report was unified. Throughout the analysis I have divided that data between the discourse of "mirreyes de outlet" (participants) the discourse used by the reporter. This helps us better understand the opaque meaning behind the report. The interviewees are four young adults who are considered "mirreyes de outlet"; throughout the segment they received the following pseudonyms: Kike, Dalia, Xavier, and Inti. Table 1 illustrates the general characteristics of the report under examination and a complete transcript of the report can be seen in Appendix 1.

Table 1. General Characteristic of Discourse

\begin{tabular}{|l|c|c|c|c|}
\hline \multirow{2}{*}{ Statistical Item } & \multicolumn{2}{|c|}{ Reporter's Discourse } & \multicolumn{2}{c|}{ Interviewee's Discourse } \\
\cline { 2 - 5 } & No. & $\%$ & No. & $\%$ \\
\hline Tokens & 481 & 42 & 672 & 58 \\
\hline Types & 304 & 63 & 389 & 57 \\
\hline Turn taking & 34 & 52 & 31 & 48 \\
\hline
\end{tabular}

\subsection{Transitivity analysis}

The transitivity analysis consists of understanding the processes that is used within the ideation function (Table 2 show the results of the analysis). Moreover, Table 3 displays some of the examples found in each of the aspects. 
Table 2. Transitivity analysis

\begin{tabular}{|l|c|c|c|c|c|}
\hline \multirow{2}{*}{ Statistical Item } & \multicolumn{2}{|c|}{ Reporters' Discourse } & \multicolumn{2}{|c|}{ Interviewee's Discourse } & Total \\
\cline { 2 - 6 } & No. & $\%$ & No. & $\%$ & $\%$ \\
\hline Material & 9 & 21 & 20 & 36 & 57 \\
\hline Mental & 2 & 5 & 18 & 33 & 38 \\
\hline Relational & 3 & 7 & 0 & 0 & 7 \\
\hline Verbal & 24 & 58 & 4 & 7 & 65 \\
\hline Behavioral & 1 & 2 & 6 & 11 & 13 \\
\hline Existential & 3 & 7 & 7 & 13 & 20 \\
\hline
\end{tabular}

Table 3. Examples of process

\begin{tabular}{|l|c|c|}
\hline Examples & Reporter's Discourse & Interviewees Discourse \\
\hline Material & $\begin{array}{c}\text { See, buy, arrive, meet, study, work, } \\
\text { discover }\end{array}$ & Post, cruise, begin \\
\hline Mental & Are, think, believe, feel, like & Forms of be \\
\hline Relational & Say, forms of be & Resist \\
\hline Verbal & Show off & Said, criticized, decided \\
\hline Behavioral & Forms of be, have, support & Forms of be \\
\hline Existential &
\end{tabular}

The participants mostly used the material process ( $51 \%$ of the time) to describe what they do. They express the following: "ando comprando cosas en el antro / I am buying things at the nightclub", "tengo una empresa / I own my own corporation", and "estudie la carrerra de derecho / I went to law school". As we can observe these quotes discuss their lifestyle by stating they go to nightclubs, owning a corporation, and having the opportunities to study. The second most used process is the mental, which was a used a $33 \%$ of the time. They discuss their likes, believes and perceptions. For instance, Dalia suggests "si no estás en la redes sociales no eres nadie / if you are not part of social media you are nobody". She believes social media has a high value, and explains that if someone is not part of it they become invisible. Another participant perceives appearances to be important and he states "yo creo que como te ven te tartan / people will treat you by the way you look". Acknowledging that your value is measured through appearance.

The reporter on the other hand mostly uses the verbal process $(58 \%)$ to provide information on the participants. However, if we analysis these quotes we can observe that most of them report the negative actions.

"Publican su apartmente vida de lujo en la internet. Inti se pasea orgulloso por las calles de la cuidad de Mexico. / They post their apparent luxurious lifestyle on the internet. Inti proudly cruises around the streets of Mexico City".

In the first quote the reporter sheds light on the false luxurious lifestyle that they portray on the internet. While in the second quote they are referring to one of the participant as a proud individual who spends his time wondering the streets of Mexico City. Both of these quotes give negative impressions of 'mirreyes de outlet.' about appearances.

Furthermore, they use the relational process to identify them as people who only care

"Kike es amante de verse bien. A Javier Redondo lo vence la moda. La moda, la

llamada boca de pato y lo excéntrico los define / Kike is a lover of good looks. Javier

loves fashion. Fashion, duckfaces, and the eccentric defines them".

They characterize Kike as a person who loves to look good, then Xavier as someone who cannot resist fashion. But most importantly they label them as eccentric. Furthermore, the 
R. R. Molinares - “Los Mirreyes de Outlet”: A Critical Discourse Analysis on a Broadcast...

reporter uses the material process (21\%) to describe activities, other than these two processes the remaining did not have a significant percentage of usage.

\subsection{Modality analysis}

This part of the analysis is concerned with examining "comments, attitudes, and evaluations in relation to the particular communication roles" (Halliday, 1971: 333). The report's purpose is descriptive, through the analysis of the verbs the results indicate that the participants are affirming all the time while the reporters affirms information $98 \%$ of the time (see Table 4). Throughout the eight minutes of the report there is only one question made by the reporter, therefore the interrogative mood is only used $2 \%$ of the time.

Table 4. Mood

\begin{tabular}{|l|c|c|c|c|}
\hline \multirow{2}{*}{ Statistical Item } & \multicolumn{2}{|c|}{ Reporters' Discourse } & \multicolumn{2}{c|}{ Interviewee's Discourse } \\
\cline { 2 - 5 } & No. & $\%$ & No. & $\%$ \\
\hline Imperative & 0 & 0 & 0 & 0 \\
\hline Affirmative & 60 & 98 & 93 & 100 \\
\hline Interrogative & 1 & 2 & 0 & 0 \\
\hline
\end{tabular}

This helps us understand that the purpose of the report is to express a certain ideology about this group of young adults. The fact that we, the audience, do not have access to the inquiries may lead us to question whether or not these had a certain ideological bias.

Moreover, the results indicate that present tense was used the most within the reporter's and interviewee's discourse (see Table 5). The usage of present tense (reporter: 68\%, interviewee $78 \%$ ) affirms that the aim of the report was to establish this as a relevant social topic. The past tense was second most used tense (reporter: 15\%, interviewee 10\%), they only use it to describe the participants' background and personal history. This is to ensure that the audience understands that they do not come from a privileged background, on the contrary they have had to work hard to maintain their position of "mirreyes de outlet".

Table 5. Use of tenses

\begin{tabular}{|l|c|c|c|c|}
\hline \multirow{2}{*}{ Statistical Item } & \multicolumn{2}{|c|}{ Reporters' Discourse } & \multicolumn{2}{c|}{ Interviewee's Discourse } \\
\cline { 2 - 5 } & No. & $\%$ & No. & $\%$ \\
\hline Present & 36 & 68 & 68 & 78 \\
\hline Past & 8 & 15 & 9 & 10 \\
\hline Infinitive & 9 & 17 & 8 & 9 \\
\hline Future & O & O & 3 & 3 \\
\hline
\end{tabular}

Now I turn to explain the attitudes and evaluation by presenting the use of adjectives. As illustrated in the table 6, the participants and the reporter use mostly positive adjectives. This could mislead us into thinking that the positive adjectives are being used to describe "los mirreyes de out". However, all the positive adjectives (reporter: $75 \%$, interviewee $67 \%$ ) are only used to depict places and things that appear in the report. For example; "lugares exclusivos / exclusive places", "vida de lujos/ luxurious lifestyle", and "sitios que sean de alto nivel / high status places". The negative adjectives (reporter: 25\%, interviewee 33\%) are used to describe the participants "lo excéntrico los define / the eccentric defines them". Repeatedly the use of adjectives gives evidence that the report does not aim at giving a positive image of the participants.

Table 6. Use of adjectives

\begin{tabular}{|l|c|c|c|c|}
\hline \multirow{2}{*}{ Statistical Item } & \multicolumn{2}{|c|}{ Reporters' Discourse } & \multicolumn{2}{c|}{ Interviewee's Discourse } \\
\cline { 2 - 5 } & No. & $\%$ & No. & $\%$ \\
\hline Positive Adjectives & 12 & 75 & 9 & 67 \\
\hline Negative Adjective & 4 & 25 & 4 & 33 \\
\hline
\end{tabular}


The reporter is mainly describing the "mirreyes de out" as a group of eccentric people, who come from a marginalized background. Through their efforts they have come to higher positions, but still have to fake a luxurious lifestyle on social media.

\subsection{Textual analysis}

In this part of the analysis I shall present the organizational structure of the report. The organization also reveals information on the intention of the report. The first lines of the report are the following:

"Exhibición, egolatría, narcisismo, engreimiento y pose. Cada vez son más los que publican su aparente vida de lujo en la internet / Exhibition, egotism, narcissism, conceit and pose. More and more people post their apparent luxurious lifestyle on the internet".

They start off by portraying a negative image on those who post a false luxurious lifestyle on the internet and call them egocentric, conceited and narcissist people. They keep this line safe by not mentioning who is responsible for this, anyhow its assumed that they are referring to "mirreyes de out". This is also the section where they present background information of the participants.

In the second part of the report the participants disclose their usual activities. The activities that they mention are: going to popular nightclubs, luxurious restaurants, shopping, and visiting styling sites. All of this information is used to confirm the idea that they are concerned with their appearance and having a luxurious lifestyle. In the third part, the reporter asks them to talk about their personal history. All of them confirm that they do not come from a privileged background on the contrary they have to work hard in order to afford the image that they want to portray. Once more, this goes back to confirming they are not part of this selected and they have to work hard to keep up with false appearances.

After they have conveyed who they are, what they do and their backgrounds the report ends by trying to soften the negative image. The program's host says "esta es la vida de esfuerzo de los 'otros' mirreyes / This is the life of effort of the other mirreyes". Now they are trying to describe them as hard-working individuals who live a life of effort. However, after all of their discourse it is impossible to gain back a positive image of the participants. Most importantly they are using the word 'other' to set them apart from the rest of society.

\section{Discussion}

"It is precisely through the mundane and seemingly trivial practices of everyday life that ideology works most freely and effectively" (Farmer, 2003: 22).

Beyond the humorous labels and popularity of this social phenomenon this report portrays a social problem of dominance and inequities. Just as Farmer states even in the trivial practices of life such a watching a television report on a Sunday afternoon we are impregnated with ideologies which are intended to dominate society. The analysis makes it evident they are using public national TV to reinforce the use of labels and stereotypes. They are discussing stereotypes as if it were humorous and trendy to call people a certain name due to their economic status.

They are approving of class division and hierarchies by saying "les dicen mirreyes de outlet porque no puede comprar más que ofertas / they are called mirreys de outlet because all the can afford are sales". Since this group does not have the economic status to afford brand prices they are marginalizing them and calling them "other" and "eccentric". Fairclough and Kress (1993) 
explain that media discourse naturalizes and neutralizes terms to employ power and ideology. This is exactly what is happening the TV host and reporter are neutralizing stereotypes and class labels.

According to Wodak (2001) language in mass media is meant to be transparent, neutral, disinterested, and an open space for public discourse. Nonetheless, this analysis shows none of these qualities, they do not give evidence of a non-bias approach to the participants.

Most importantly since all the report is affirmative there are dangerous ideologies presented. First, they promote the use of social media by including the following quote "Es algo que está de moda, si no estás en las redes sociales no eres nadie / Social media is trendy, therefore if you are not part of social media you are nobody". They depict social media as trendy but they are also implicitly convincing people to be part of social media otherwise they are not part of the picture of society. It's as if those who do not use social media are invisible individuals.

Furthermore, they are promoting the importance of physical appearance and luxurious lifestyles. They use the following quotes:

"Yo creo que como te ven te tartan. A mí me gustan muchísimo los relojes y todo lo que me guste me lo compro te trae ganancia aparte de que todas las mujeres se te quedan viendo. Sí realmente me gusta consentirme, tratarme bien / I believe you are treated according to your looks. I really like watches, and everything else I see and like I buy, it all gives you something in return, even women stare at you. I really enjoy pampering myself".

In other words, they are letting us know that we are treated according to our looks. Therefore, they should be worried about buying objects that make us look good. The male participant even suggests that having expensive watches helps him have women's attention. In a further statement the participants also give the impression that we should pamper ourselves.

\section{Conclusion}

Throughout this critical discourse analysis, it is apparent that what seems to be an innocent, humorous, and updated TV report result to reinforce the social divisions, stereotypes, and the importance of luxurious lifestyles. The transitivity analysis reports that the processes that were majority employed were the verbal, material, and mental. The reporter used a verbal process $58 \%$ of time, this was to voice the participants' ideas, while the material process (28\%) was used to describe the activities that 'mirreyes de outlet' perform. On the other hand, the interviewees reported their activities to do so, they used a verbal process (65\%) but in addition to other processes they significantly used the mental process (38\%) to discuss their ideologies. The report was scripted in an affirmative mood; the reporter used this mood $98 \%$ while the interviewee a $100 \%$ of the time. Correspondingly, most of the content was expressed in the present tense.

Considering the results, it is prejudicial that in a broken society, mass media is used to reinforce divisions. In Mexico 80\% of the population is said to live in poverty and each day greater inequities exist among the country's society (Feixa, 1998). The situation is unfortunate however, it is our decision to be aware of the situation and reject these ideologies that are trying to position themselves in our society. Most important there is a need to understand that we are all human beings, and no one has the right to label or stereotype us due to appearance or socioeconomic.

\section{Acknowledgements}

I would like to first thank, God who strengths me. My family who is always there to support and encourage me. I am also grateful for all of my professors at the University of Guanajuato, especially Dr. Troy Crawford Lewis, who gave us the freedom and confidence to work 
on this analysis. His unique teaching approach has had an important impact on my professional development.

This research did not receive any specific grant from funding agencies in the public, commercial, or not-for-profit sectors.

Conflicts of interest: none

\section{References}

Espinosa, O. N., \& Henderson, G. O. (2012). Identidades juveniles de principios del siglo XXI: Los Mirreyes. Antropología Experimental, 12(15), 193-217.

Fairclough, N. (1985). Critical and descriptive goals in discourse analysis. Journal of Pragmatics, 9(7), 4063.

Fairclough, N., \& Kress, G. (1993). Critical discourse analysis. Unpublished manuscript.

Fairclough, N., \& Wodak, R. (1997). Critical discourse analysis. In: van Dijk (Ed.), Discourse studies: A multidisciplinary introduction (pp. 258-284). London: Sage.

Feixa, C. (1998). Las culturas juveniles en México. Retrieved from:

http://educiac.org.mx/pdf/Biblioteca/Juventud e Identidad/o16LasCulturasJuveniles en Mexico.pdf.

Foucault, M. (1996). Diskurs und Wahrheit. Berkeley Lectures. Berlin: Merve.

Giddens, A. (1991). Modernity and self-identity: Self and society in the late modern age. Cambridge: Polity.

Habermas, J. (1996). Die Einbeziehung des Anderen. Studien zur politischen Theorie. Frankfurt: Suhrkamp.

Halliday, M. A. K. (1978). Language as social semiotic. London: Arnold.

Haratyan, F. (2011). Halliday's SFL and social meaning. IPEDR (17), 260-264.

Jagose, A. (2003). The invention of lifestyle. In: Martin, F. (Ed.), Interpreting everyday culture (pp. 109123). Oxford: Oxford University Press.

Martin, F. (Ed.). (2003). Interpreting everyday culture. Oxford: Oxford University Press.

van Dijk, T. A. (1986). Racism in the Press. London: Arnold.

Wodak, R., \& Meyer, M. (Eds.). (2009). Methods for critical discourse analysis. London: Sage. 
R. R. Molinares - “Los Mirreyes de Outlet”: A Critical Discourse Analysis on a Broadcast...

C O A $\mathbf{s}$ 